\title{
The structure in the solid state and in solution of 3(5)-trifluoromethyl-4,5(3)-polymethylenepyrazoles
}

\author{
Marcos A. P. Martins, ${ }^{a}$ Nilo Zanatta, ${ }^{a}$ Helio G. Bonacorso, ${ }^{a}$ Fernanda A. Rosa, ${ }^{a}$ \\ Rosa M. Claramunt, ${ }^{b} \mathbf{M}^{a}$ Ángeles García, ${ }^{b}$ M. Dolores Santa María, ${ }^{b}$ and José Elguero ${ }^{c *}$ \\ ${ }^{a}$ Núcleo de Química de Heterociclos (NUQUIMHE ), Departamento de Química, \\ Universidade Federal de Santa Maria, 97. 105- 900 Santa Maria, RS, Brazil \\ ${ }^{b}$ Departamento de Química Orgánica y Bio-Orgánica, Facultad de Ciencias, UNED, \\ Senda del Rey, 9, E-28040 Madrid, Spain \\ ${ }^{c}$ Instituto de Química Médica, CSIC, Juan de la Cierva 3, E-28006 Madrid, Spain \\ E-mail: iqmbe17@iqm.csic.es
}

Dedicated to Professor Armand Lattes for his 50 years of professorship

\begin{abstract}
The tautomerism of three polymethylenepyrazoles bearing at position 3(5) a trifluoromethyl group has been studied by NMR in solution $\left({ }^{1} \mathrm{H},{ }^{13} \mathrm{C},{ }^{15} \mathrm{~N},{ }^{19} \mathrm{~F}\right)$ and in the solid state $\left({ }^{13} \mathrm{C},{ }^{15} \mathrm{~N}\right)$. The conclusion is that in all cases they are $3-\mathrm{CF}_{3}$ tautomers. DFT calculations have been carried out to compare these compounds to the analogous $3-\mathrm{CH}_{3}$ derivatives and to assess the MillsNixon effect in the case of trimethylene derivatives as well as the effect of replacing a $\mathrm{CH}_{3}$ by a $\mathrm{CF}_{3}$ group on the tautomerism.
\end{abstract}

Keywords: Tautomerism, pyrazoles, trifluoromethyl, NMR, CPMAS, DFT calculations

\section{Introduction}

In this paper we present a comparative study of three pairs of methyl/trifluoromethyl pyrazoles concerning tautomerism and NMR properties, determined both in solution and in the solid state. The experimental data of the methyl derivatives, $\mathbf{1}, \mathbf{3}$ and $\mathbf{5}$, are from the literature [1,2]. Theoretical calculations, at different levels, have been carried out on pairs of tautomers, $1 \mathrm{H}$ a and $2 H \mathbf{b}$, of pyrazoles 1-6. 
<smiles>Cc1n[nH]c2c1CCCC2</smiles>

$1 a$<smiles>Cc1[nH]nc2c1CCCC2</smiles>

$1 b$<smiles>FC(F)(F)c1n[nH]c2c1CCCC2</smiles>

2a

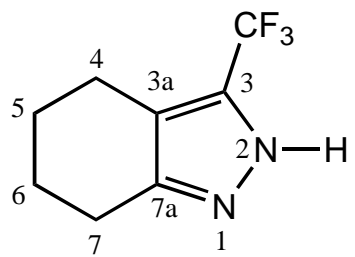

2b<smiles>Cc1n[nH]c2c1CC(C)CC2</smiles>

3a<smiles>Cc1[nH]nc2c1CC(C)CC2</smiles>

$3 b$<smiles>CC1CCc2[nH]nc(C(F)(F)F)c2C1</smiles>

4a

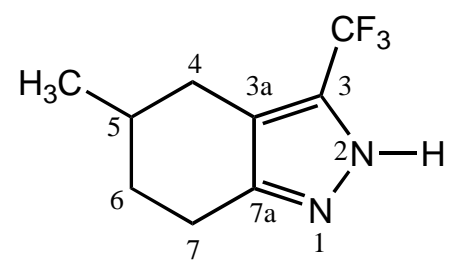

4b<smiles>Cc1n[nH]c2c1CCCCC2</smiles>

$5 a$<smiles>Cc1[nH]nc2c1CCCCC2</smiles>

$5 b$

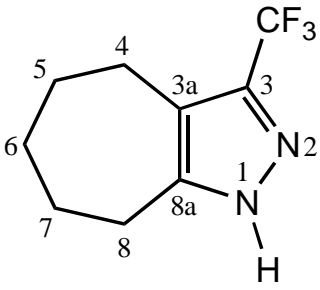

6a

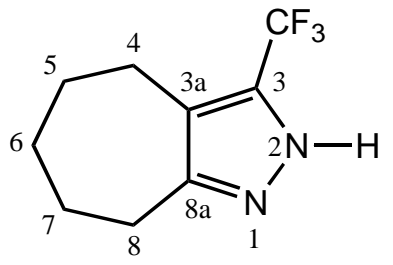

6b

Scheme 1. The six pairs of 3(5)-methyl/trifluoromethylpyrazoles

The aim of this work is to determine if the structural information can be transferred from the well-known methyl pyrazoles, 1, 3, 5, to the less studied trifluoromethylpyrazoles, 2, 4, 6 [35]. Regarding 3(5),4-polymethylenepyrazoles (the IUPAC name of tetramethylene-pyrazoles is tetrahydroindazoles and pentamethylenepyrazoles are also named hexahydrocyclohepta[c] pyrazoles), they are known but not with perfluorinated substituents [6-9].

\section{Results and Discussion}

\section{NMR studies in solution}

The NMR results in solution of compounds $\mathbf{2}, \mathbf{4}$ and $\mathbf{6}$ have been gathered in Tables 1 ( ${ }^{1} \mathrm{H}$ NMR) and $2\left({ }^{13} \mathrm{C},{ }^{15} \mathrm{~N}\right.$ and $\left.{ }^{19} \mathrm{~F} \mathrm{NMR}\right)$. 
Table 1. ${ }^{1} \mathrm{H}$ NMR results ( $\delta$ in ppm, $J$ in Hz). Solvent: DMSO- $\mathrm{d}_{6}$

\begin{tabular}{lcccccc}
\hline $\begin{array}{l}\text { Pyra- } \\
\text { zole }\end{array}$ & 4 & 5 & 6 & 7 & 8 & NH \\
\hline $\mathbf{2}$ & $2.48(\mathrm{t})^{*}$ & $1.64-1.71(\mathrm{~m})$ & $1.68-1.75(\mathrm{~m})$ & $2.59(\mathrm{t})^{*}$ & --- & $13.06(\mathrm{~s})$ \\
$\mathbf{4}$ & $2.44(\mathrm{eq})(\mathrm{m})$ & $1.22(\mathrm{eq} \mathrm{CH})$ & $1.89(\mathrm{eq})(\mathrm{m})$ & $1.57(\mathrm{eq})(\mathrm{m})$ & -- & $13.17(\mathrm{~s})$ \\
& $2.50(\mathrm{ax})(\mathrm{m})$ & $2.82(\mathrm{ax})(\mathrm{q})$ & $1.31(\mathrm{ax})(\mathrm{m})$ & $1.81(\mathrm{ax})(\mathrm{m})$ & -- & \\
$\mathbf{6}$ & $2.55(\mathrm{t}) *$ & $1.55-1.62(\mathrm{~m})$ & $1.74-1.80(\mathrm{~m})$ & $1.55-1.62(\mathrm{~m})$ & $2.71(\mathrm{t})^{*}$ & $13.03(\mathrm{~s})$ \\
\hline
\end{tabular}

* Sum of $11-12 \mathrm{~Hz}$ corresponding to two ${ }^{3} J_{\mathrm{HH}}$ (in this kind of symmetrical spin-system, observation of a triplet for a methylene group does not imply necessarily that the coupling constants are equal).

Table $2 .{ }^{13} \mathrm{C}$ and ${ }^{15} \mathrm{~N}$ NMR results ( $\delta$ in ppm, $J$ in Hz). Solvent: DMSO-d 6

\begin{tabular}{|c|c|c|c|c|c|}
\hline Pyrazole & 3 & За & 4 & 5 & 6 \\
\hline 2 & $\begin{array}{l}137.4 \\
{ }^{2} J_{\mathrm{CF}}=35.2\end{array}$ & 112.9 & 19.3 & 21.7 & 22.2 \\
\hline 4 & $\begin{array}{l}137.3 \\
{ }^{2} J_{\mathrm{CF}}=35.3\end{array}$ & 112.9 & 19.5 & 26.8 & 30.9 \\
\hline 6 & $\begin{array}{l}138.4 \\
{ }^{2} J_{\mathrm{CF}}=34.6\end{array}$ & 117.2 & 23.2 & 28.0 & 31.0 \\
\hline & 7 & 8 or $5-\mathrm{CH}_{3}$ & $7 a$ or $8 a$ & $\mathrm{CF}_{3}{ }^{(\mathrm{a})}$ & $\mathrm{NH}$ \\
\hline 2 & 20.3 & --- & 140.3 & $\begin{array}{l}122.5 \\
{ }^{1} J_{\mathrm{CF}}=267.5\end{array}$ & $\begin{array}{l}-174.2 \\
{ }^{1} J_{\mathrm{NH}}=105.2\end{array}$ \\
\hline 4 & 21.1 & $19.5\left(\mathrm{CH}_{3}\right)$ & 145.0 & $\begin{array}{l}122.5 \\
{ }^{1} J_{\mathrm{CF}}=268.7\end{array}$ & $\begin{array}{l}-174.9 \\
{ }^{1} J_{\mathrm{NH}}=103.9\end{array}$ \\
\hline 6 & 26.8 & 25.8 (C8) & 144.7 & $\begin{array}{l}122.5 \\
{ }^{1} J_{\mathrm{CF}}=269.0\end{array}$ & $\begin{array}{l}-171.2 \\
{ }^{1} J_{\mathrm{NH}}=104.8\end{array}$ \\
\hline
\end{tabular}

(a) In ${ }^{19} \mathrm{~F}$ NMR, the $\mathrm{CF}_{3}$ group appears at $-59.8 \mathrm{ppm}(2)$; $-59.8 \mathrm{ppm}(4)$; $-59.1 \mathrm{ppm}$ (6).

The assignments are based on literature results on compounds $\mathbf{1}, \mathbf{3}$ and $\mathbf{5}$ and their $\mathrm{N}$ methyl derivatives [7,8], on NMR studies of trifluoromethylpyrazoles [3] as well as on 2D NMR experiments. The ${ }^{15} \mathrm{~N}$ signal is that of the $\mathrm{NH}$, the other one is not observed.

It is worth mentioning that the $\mathrm{C} 3$ and $\mathrm{CF}_{3}$ signals (both ${ }^{13} \mathrm{C}$ and ${ }^{19} \mathrm{~F}$ ) are almost identical. This indicates a very similar $\mathbf{a} / \mathbf{b}$ tautomer composition for pyrazoles 2, $\mathbf{4}$ and $\mathbf{6}$ to the point that the determination of the predominant tautomer for any of them results in determining it for all three pyrazoles. 
From a large collection of ${ }^{13} \mathrm{C}$ chemical shifts of pyrazoles [10] it is possible to estimate the chemical shifts of $\mathbf{2 a}$ and $\mathbf{2} \mathbf{b}$ from those of 1-methyl- and 2-methyl-tetrahydroindazoles unsubstituted at position 3 and from the effects of a trifluoromethyl group at positions 3 and 5 of pyrazoles:
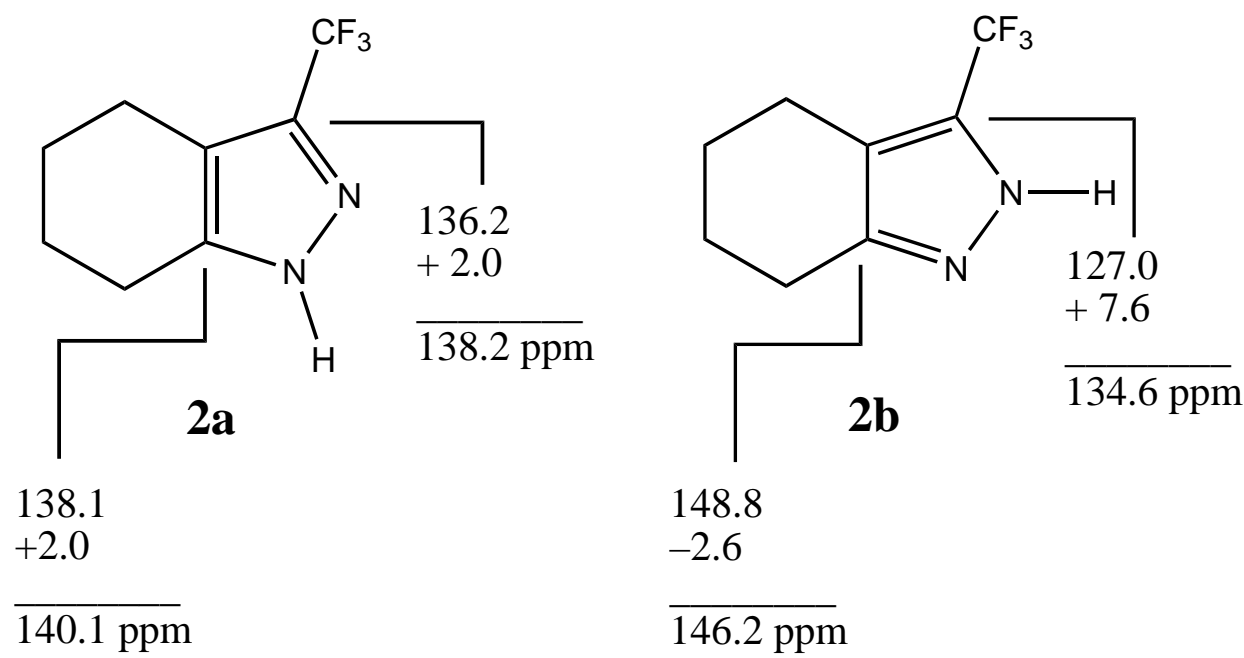

The experimental data (Table 3), 137.4 (C3) and 140.3 (C7a) correspond to tautomer 2a, thus all are $3-\mathrm{CF}_{3}$ tautomers $\mathbf{2 a}$, $\mathbf{4 a}$ and $\mathbf{6 a}$. Note that the signal of the $\mathrm{C7a}(\mathrm{C} 8 \mathrm{a})$ carbon atom is much more dependent on the saturated ring than C3. In general and by analogy with literature results $[3,7,8]$, the signals of $\mathbf{b}$ tautomers, $\mathbf{2} \mathbf{b}, \mathbf{4} \mathbf{b}$ and $\mathbf{6 b}$, are expected at different positions.

\section{NMR studies in the solid state}

The NMR results obtained in the solid state using the CPMAS technique are reported in Table 3.

The results of Table 3 are of the utmost importance for the present work. They must be commented in detail:

i) Although in the three cases it appears that two molecules are present, by comparison with NMR data in solution, it is clear that both families of signals belong to tautomer $\mathbf{a}$ : $\mathbf{2 a}, \mathbf{4 a}$ and $6 \mathbf{a}$.

ii) By deconvolution we have estimated the proportion of the two molecules always being $60 \%$ of the major component and $40 \%$ of the minor one and this for $2 \mathbf{a}$, $4 \mathbf{a}$ and $\mathbf{6 a}$. The estimated error is $\pm 3 \%$. The two molecules should correspond to two independent molecules in the crystal that probably differ in their conformation.

iii) Most signals of pyrazole 4a (both molecules) are broad. This broadening is not due to tautomerism since $\mathbf{4 b}$ is absent. Therefore, we assigned it to conformational motions involving the polymethylene chain. This is probably related to the fact that in the DSC experiments (see experimental part) only $\mathbf{4}$ shows a phase transition. 
Table $3 .{ }^{13} \mathrm{C}$ and ${ }^{15} \mathrm{~N}$ CPMAS NMR results ( $\delta$ in ppm)

\begin{tabular}{|c|c|c|c|c|c|c|c|}
\hline & rrazole & 3 & 3a & 4 & 5 & 6 & 7 \\
\hline \multirow[t]{2}{*}{2} & major & 137.9 & 114.0 & 19.0 & 21.7 & 22.4 & 20.5 \\
\hline & minor & 141.0 & 114.0 & 19.2 & 21.7 & 23.2 & 19.7 \\
\hline \multirow[t]{2}{*}{4} & major & 138.2 & 113.5 & broad & broad & broad & broad \\
\hline & minor & 138.2 & 112.9 & broad & broad & broad & broad \\
\hline \multirow[t]{3}{*}{6} & major & 139.1 & 117.8 & 23.8 & 28.3 & 31.8 & 26.5 \\
\hline & minor & 145.2 & 117.8 & 23.8 & 28.7 & 30.8 & 26.5 \\
\hline & & 8 or $5-\mathrm{CH}_{3}$ & $7 a$ or $8 a$ & $\mathrm{CF}_{3}$ & & $\mathrm{~N} 1$ & N2 \\
\hline \multirow[t]{2}{*}{2} & & --- & 141.8 & 122.7 & & -174.4 & -98.2 \\
\hline & & & 141.8 & 122.7 & & -173.2 & -99.1 \\
\hline \multirow[t]{2}{*}{4} & & broad $\left(\mathrm{CH}_{3}\right)$ & 146.5 & 122.8 & & -174.9 & -98.2 \\
\hline & & broad $\left(\mathrm{CH}_{3}\right)$ & 146.5 & 122.8 & & -174.9 & -98.2 \\
\hline \multirow[t]{2}{*}{6} & & 26.5 (C8) & 145.2 & 122.3 & & -171.4 & -101.7 \\
\hline & & 26.5 (C8) & 145.9 & 122.3 & & -169.4 & -103.0 \\
\hline
\end{tabular}

\section{Gas phase values (theoretical calculations)}

The tautomerism of polymethylenepyrazoles has been the subject of many calculations in relation with the Mills-Nixon effect. We have been the first to extend the Mills-Nixon effect from its original definition concerning resonance forms [11] to the equilibrium present in tautomerism, first to pyrazoles [8,12] and then to enols of $\beta$-diketones [13]. These studies reported that small rings favor the tautomers $\mathbf{b}$ with an endo single bond. Since the 5-methyl group of the $\mathbf{3}$ and $\mathbf{4}$ series should produce a negligible effect on the tautomerism, we have decided to study pyrazoles $\mathbf{1}$ and $\mathbf{5}$ (previously reported [8]) and $\mathbf{2}$ and $\mathbf{6}$. To these four pyrazoles we have added the corresponding five-membered derivatives (trimethylene pyrazoles) $\mathbf{7}$ and $\mathbf{8}$.

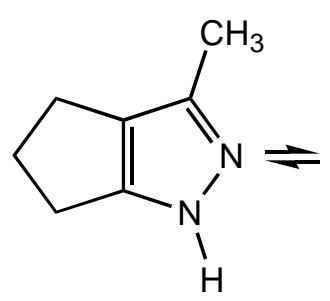

$7 a$

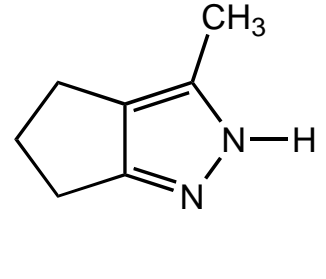

$7 \mathbf{b}$<smiles>FC(F)(F)c1[nH]nc2c1CCC2</smiles>

8a $\mathbf{8 b}$

We have reported in Table 4 the results of the calculations of the twelve pyrazoles in what energy aspects are concerned. 
Table 4. Energy of the most stable tautomer (in hartree), the difference in energy between both tautomers (in $\mathrm{kJ} \mathrm{mol}^{-1}$ ) and the dipole moment (in D). B3LYP/6-31G** calculations

\begin{tabular}{lllllll}
\hline $\begin{array}{l}\text { Ring } \\
\text { size }\end{array}$ & No. & $\mathrm{R}$ & $\begin{array}{l}\text { Most stable } \\
\text { tautomer }\end{array}$ & $\begin{array}{l}\text { Difference in } \\
\text { energy }\end{array}$ & $\begin{array}{l}+\mathrm{ZPE} \\
\text { correction }\end{array}$ & Dipole moment \\
\hline 5 & $\mathbf{7}$ & $\mathrm{CH}_{3}$ & $\mathbf{7 b}:-382.2639$ & $\mathbf{7 b}-\mathbf{7 a}:-3.10$ & $\mathbf{7 b}-\mathbf{7 a}:-3.71$ & $\mathbf{7 a}: 2.39 ; \mathbf{7 b}: 2.43$ \\
5 & $\mathbf{8}$ & $\mathrm{CF}_{3}$ & $\mathbf{8 b}:-679.9750$ & $\mathbf{8 b}-\mathbf{8 a}:-2.16$ & $\mathbf{8 b}-\mathbf{8 a}:-2.85$ & $\mathbf{8 a}: 5.10 ; \mathbf{8 b}: 1.12$ \\
6 & $\mathbf{1}$ & $\mathrm{CH}_{3}$ & $\mathbf{1 a}:-421.5977$ & $\mathbf{1 b}-\mathbf{- 1 a}: 2.22$ & $\mathbf{1 b}-\mathbf{1 a}: 2.71$ & $\mathbf{1 a}: 2.46 ; \mathbf{1 b}: 2.40$ \\
6 & $\mathbf{2}$ & $\mathrm{CF}_{3}$ & $\mathbf{2 a}:-719.3105$ & $\mathbf{2 b}-\mathbf{2 a}: 3.55$ & $\mathbf{2 b}-\mathbf{2 a}: 3.87$ & $\mathbf{2 a}: 5.08 ; \mathbf{2 b}: 1.01$ \\
7 & $\mathbf{5}$ & $\mathrm{CH}_{3}$ & $\mathbf{5 a}:-460.9137$ & $\mathbf{5 b}-\mathbf{5 a}: 0.29$ & $\mathbf{5 b}-\mathbf{5 a}: 0.78$ & $\mathbf{5 a}: 2.47 ; 5 \mathbf{b}: 2.36$ \\
7 & $\mathbf{6}$ & $\mathrm{CF}_{3}$ & $\mathbf{6 a}:-758.6266$ & $\mathbf{6 b}-\mathbf{6 a}: 1.73$ & $\mathbf{6 b}-\mathbf{6 a}: 1.32$ & $\mathbf{6 a}: 5.10 ; \mathbf{6 b}: 1.00$ \\
\hline
\end{tabular}

The results of Table 4 correspond to the balance between two factors:

- The preference for the 3-position (i.e. $1 H$-tautomers a) increases in average $0.85 \mathrm{~kJ} \mathrm{~mol}^{-1}$ from $\mathrm{CH}_{3}$ to $\mathrm{CF}_{3}$ being slightly dependent on the ring size.

- The $\mathbf{a} / \mathbf{b}$ tautomerism changes from Mills-Nixon in the case of $\mathbf{7 / 8}\left(-3.3 \mathrm{~kJ} \mathrm{~mol}^{-1}\right)$, to neutral in the case of $\mathbf{5} / \mathbf{6}\left(+1.0 \mathrm{~kJ} \mathrm{~mol}^{-1}\right)$, to "anti-Mills-Nixon" in the case of $\mathbf{1} / \mathbf{2}\left(+3.3 \mathrm{~kJ} \mathrm{~mol}^{-1}\right)$ The variation with the ring size is not linear as can be seen in Fig. 1.

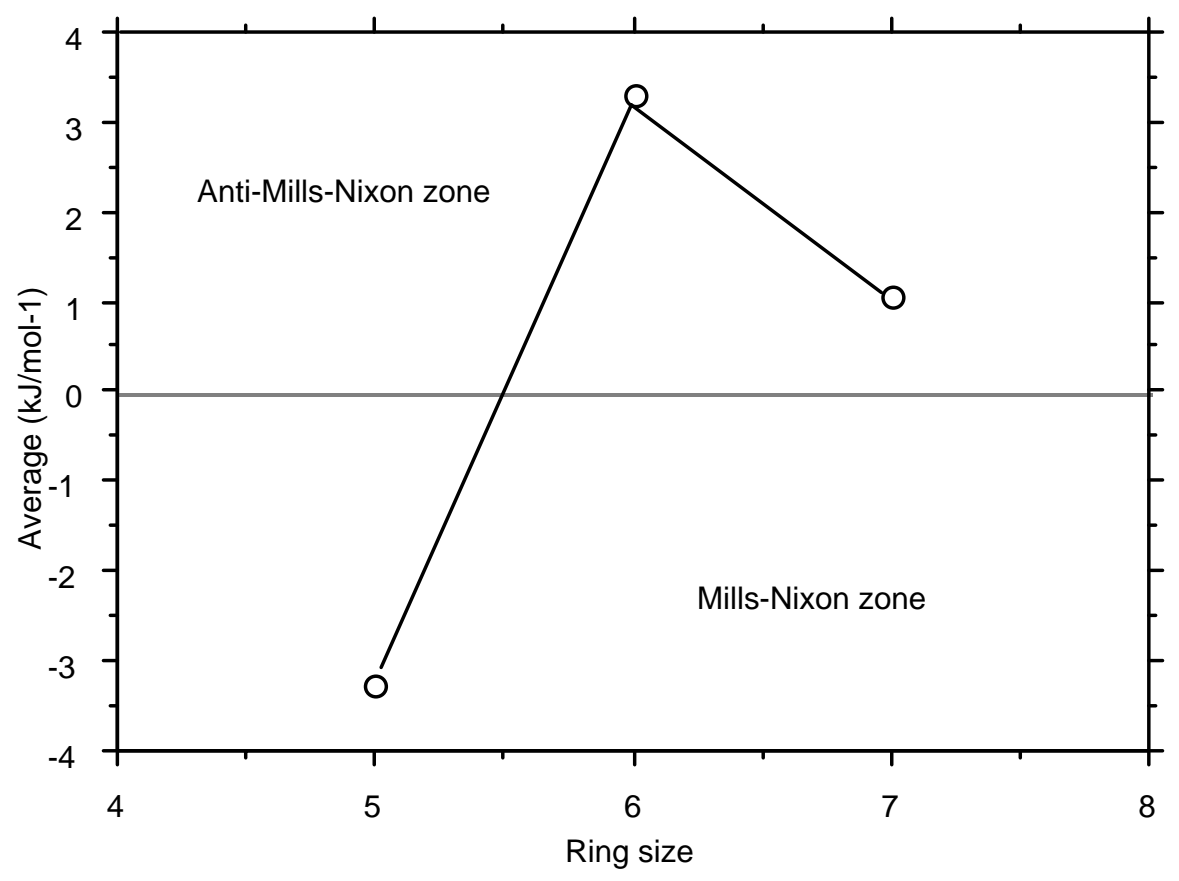

Figure 1. Differences in energy (ZPE corrected) of the average values (methyl and trifluoromethyl substituents) derivatives against the ring size: $5(7, \mathbf{8}), 6(\mathbf{1 , 2})$ and $7(5,6)$. 
In the case of the methyl derivatives the dipole moments are independent of the tautomerism because a methyl group is electronically similar to the first methylene of the polymethylene chain. Taking into account the considerable increase in dipole moments on going from $\mathbf{b}$ to $\mathbf{a}$ in the case of the trifluoromethyl derivatives (Table 4), the proportion of tautomer $\mathbf{a}$ should increase in solution compared to the gas phase; this is consistent with the fact that only $\mathbf{2 a}$ and 6a were found experimentally.

\section{Conclusions}

Replacing a $\mathrm{CH}_{3}$ by a $\mathrm{CF}_{3}$ results in a very small increase in the stability of the $1 \mathrm{H}$-tautomer a. Although at first glance this seems to correspond to the fact that electron-withdrawing substituents prefer the 3-position of the pyrazole ring, an analysis of the tautomerism of many pyrazoles bearing different substituents at position 3(5), shows that the 3(5) preference cannot be explained by simple electronic considerations [14-16]. The present work quantifying the effect of the replacement of a methyl by a trifluoromethyl group contributes to the general understanding of substituent effects on the tautomerism of pyrazoles.

\section{Experimental Section}

General Procedures. The compounds were prepared similarly to other trifluoromethylpyrazoles $[17,18]$. To a solution of the corresponding trifluoroacetylcycloalkanone $(15 \mathrm{mmol})$ in ethanol $(15 \mathrm{~mL})$ was added rapidly a solution of hydrazine hydrochloride $(18 \mathrm{mmol})$ in ethanol $(15 \mathrm{~mL})$ at room temperature. The mixture was stirred under reflux $6 \mathrm{~h}$. The excess of hydrazine hydrochloride was filtered off and the solvent was removed in a rotatory evaporator. The reaction mixture was extracted with chloroform (3 x $20 \mathrm{~mL})$ and dried with sodium carbonate. The solvent was removed in a rotatory evaporator and the product was purified by column chromatography (silica gel 230 - 240 mesh, $30 \mathrm{~cm}$ column, eluent hexane). Yields $>80 \%$. The purity and the melting points were determined by DSC with a SEIKO DSC connected to a Model SSC5200H Disk Station. Thermograms (sample size 0.003-0.010 g) were recorded with a scan rate of $5.0{ }^{\circ} \mathrm{C} \mathrm{min.}{ }^{-1}$. Mass spectra (HRMS) at $70 \mathrm{eV}$ using electron impact mode was performed on a VG Autospec spectrometer in the "Laboratorio de Espectrometría de Masas-UAM, Madrid".

3-(Trifluoromethyl)-4,5,6,7-tetrahydro- $1 H$-indazole (2): m.p. $121.9^{\circ} \mathrm{C}$, HRMS: calculated for $\mathrm{C}_{8} \mathrm{H}_{9} \mathrm{~F}_{3} \mathrm{~N}_{2}$, 190.07178; found 190.07201.

5-Methyl-3-(trifluoromethyl)-4,5,6,7-tetrahydro- $1 H$-indazole (4): m.p. 155.9 and $160.6{ }^{\circ} \mathrm{C}$ (phase transition), HRMS: calculated for $\mathrm{C}_{9} \mathrm{H}_{11} \mathrm{~F}_{3} \mathrm{~N}_{2}$, 204.08743; found 204.08791.

3-(Trifluoromethyl)-1,4,5,6,7,8-hexahydrocyclohepta[c]pyrazole (6): m.p. $154.1{ }^{\circ} \mathrm{C}$, HRMS: calculated for $\mathrm{C}_{9} \mathrm{H}_{11} \mathrm{~F}_{3} \mathrm{~N}_{2}$, 204.08743; found 204.08735 . 
NMR Spectroscopy. Solution. The spectra were recorded on a Bruker DRX 400 (9.4 Tesla, $400.13 \mathrm{MHz}$ for ${ }^{1} \mathrm{H}, 376.50 \mathrm{MHz}$ for ${ }^{19} \mathrm{~F}, 100.62 \mathrm{MHz}$ for ${ }^{13} \mathrm{C}$ and $40.56 \mathrm{MHz}$ for ${ }^{15} \mathrm{~N}$ ) spectrometer with a 5-mm inverse-detection $\mathrm{H}$-X probe equipped with a z-gradient coil for ${ }^{1} \mathrm{H}$,

${ }^{13} \mathrm{C}$ and ${ }^{15} \mathrm{~N}$; for ${ }^{19} \mathrm{~F}$ we used a 5-mm QNP direct-detection probe equipped with a z-gradient coil. In all cases the spectra were recorded at $300 \mathrm{~K}$ at a concentration of $0.07 \mathrm{M}$. Chemical shifts $(\delta$ in ppm) are given from internal solvent, DMSO- $\mathrm{d}_{6} 2.49$ for ${ }^{1} \mathrm{H}$ and 39.5 for ${ }^{13} \mathrm{C}$, and for ${ }^{15} \mathrm{~N}$ and ${ }^{19} \mathrm{~F}$ NMR, nitromethane $(0.00)$ and one drop of $\mathrm{CFCl}_{3}$ in $\mathrm{CDCl}_{3}(0.00)$ were used as external references. Typical parameters for ${ }^{1} \mathrm{H}$ NMR spectra were spectral width $6400 \mathrm{~Hz}$ and resolution $0.39 \mathrm{~Hz}$ per point. Typical parameters for ${ }^{19} \mathrm{~F}$ NMR spectra were spectral width $29070 \mathrm{~Hz}$, pulse width $13.75 \mu \mathrm{s}$ at an attenuation level of $-6 \mathrm{~dB}$ and resolution $0.89 \mathrm{~Hz}$ per point. Typical parameters for ${ }^{13} \mathrm{C}$ NMR spectra were spectral width $20500 \mathrm{~Hz}$, pulse width $10.6 \mu$ s at an attenuation level of $-6 \mathrm{~dB}$ and resolution $0.63 \mathrm{~Hz}$ per point; WALTZ-16 was used for broadband proton decoupling. 2D $\left({ }^{1} \mathrm{H}-{ }^{1} \mathrm{H}\right)$ gs-COSY and inverse proton detected heteronuclear shift correlation spectra, $\left({ }^{1} \mathrm{H}^{13} \mathrm{C}\right)$ gs-HMQC, $\left({ }^{1} \mathrm{H}^{13}{ }^{13} \mathrm{C}\right)$ gs-HMBC and $\left({ }^{1} \mathrm{H}^{15} \mathrm{~N}\right)$ gs-HMBC, were acquired and processed using standard Bruker NMR software and in non-phase-sensitive mode. Gradient selection was achieved through a 5\% sine truncated shaped pulse gradient of $1 \mathrm{~ms}$. Solid state. ${ }^{13} \mathrm{C}(100.73 \mathrm{MHz})$ and ${ }^{15} \mathrm{~N}(40.60 \mathrm{MHz})$ CPMAS NMR spectra were obtained on a Bruker WB 400 spectrometer at $300 \mathrm{~K}$ using a $4 \mathrm{~mm}$ DVT probehead. Samples were carefully packed in a 4-mm diameter cylindrical zirconia rotors with Kel-F end-caps. Operating conditions involved $3.2 \mu \mathrm{s} 90^{\circ}{ }^{1} \mathrm{H}$ pulses and decoupling field strength of $78.1 \mathrm{kHz}$ by TPPM sequence. ${ }^{13} \mathrm{C}$ spectra were originally referenced to a glycine sample and then the chemical shifts were recalculated to the $\mathrm{Me}_{4} \mathrm{Si}$ (for the carbonyl atom $\delta$ (glycine) $=176.1 \mathrm{ppm}$ ) and ${ }^{15} \mathrm{~N}$ spectra to ${ }^{15} \mathrm{NH}_{4} \mathrm{Cl}$ and then converted to nitromethane scale using the relationship: $\delta^{15} \mathrm{~N}$ (nitromethane) $=$ $\delta^{15} \mathrm{~N}$ (ammonium chloride) - $338.1 \mathrm{ppm}$. The typical acquisition parameters for ${ }^{13} \mathrm{C}$ CPMAS were: spectral width, $40 \mathrm{kHz}$; recycle delay, $5 \mathrm{~s}$; acquisition time, $30 \mathrm{~ms}$; contact time, $2 \mathrm{~ms}$; and spin rate, $12 \mathrm{kHz}$. And for ${ }^{15} \mathrm{~N}$ CPMAS were: spectral width, $40 \mathrm{kHz}$; recycle delay, $5 \mathrm{~s}$; acquisition time, $35 \mathrm{~ms}$; contact time, $6 \mathrm{~ms}$; and spin rate, $6 \mathrm{kHz}$.

Computational details. Theoretical calculations were carried out at the B3LYP/6-31G** level $[19,20]$ using the Titan version 1.0 .5 for Windows 98 package. Particular care has to be taken with the pentamethylene derivatives $\mathbf{5}$ and $\mathbf{6}$ because there are several conformations of the seven-member ring that are minima. The absolute minimum corresponds to a pseudo-chair conformation, typical of cycloheptene [21].

\section{Acknowledgements}

The Spanish authors acknowledge grants from the Ministry of Science and Education (Project nos. BQU2003-00976 and BQU2003-01251). The Brazilian authors thank the Conselho Nacional de Desenvolvimento Científico e tecnológico (CNPq/PADCT), Fundação de Amparo à pesquisa do Estado do Rio Grande do Sul (FAPERGS) for financial support. The fellowships 
from CNPq, CAPES and FAPERGS are also acknowledged. Dr. Ibon Alkorta support is greatly acknowledged.

\section{References}

1. Elguero, J.; Yranzo, G. I.; Laynez, J.; Jiménez, P., Menéndez, M.; Catalán, J., de Paz, J. L. G.; Anvia, F.; Taft, R. W. J. Org. Chem. 1991, 56, 3942.

2. Hargittai, I.; Brunvoll, J.; Foces-Foces, C.; Llamas-Saiz, A. L.; Elguero, J. J. Mol. Struct. 1993, 291, 211.

3. Elguero, J.; Fruchier, A.; Jagerovic, N.; Werner, A. Org. Prep. Proc. Int. 1995, 27, 33.

4. Martins, M. A. P.; Blanco, R. F.; Pereira, C. M. P.; Beck, P.; Brondani, S.; Cunico, W.; Zimmermann, N. E. K.; Bonacorso, H. G.; Zanatta, N. J. Fluor. Chem. 2002, 118, 69.

5. Braibante, M. E. F.; Clar, G.; Martins, M. A. P. J. Heterocycl. Chem. 1993, 30, 1159; Bonacorso, H. G.; Wastowski, A. D.; Zanatta, N.; Martins, M. A. P.; Naue, J. A. J. Fluor. Chem. 1998, 92, 23; Flores, A. F. C.; Brondani, S.; Zanatta, N.; Rosa, A.; Martins, M. A. P. Tetrahedron Lett. 2002, 43, 8701.

6. Bardou, L.; Elguero, J.; Jacquier, R. Bull. Soc. Chim. Fr. 1967, 289 and 297.

7. López, C.; Claramunt, R. M.; Trofimenko, S.; Elguero, J. Can. J. Chem. 1993, 71, 678.

8. Martínez, A.; Jimeno, M. L.; Elguero, J.; Fruchier, A. New J. Chem. 1994, 18, 269.

9. Foces-Foces, C.; Hager, O.; Jagerovic, N.; Jimeno, M. L.; Elguero, J. Chem. Eur. J. 1997, 3, 121.

10. Begtrup, M.; Boyer, G.; Cabildo, P.; Cativiela, C.; Claramunt, R. M.; Elguero, J.; García, J. I.; Toiron, C.; Vedsø, P. Magn. Reson. Chem. 1993, 31, 107.

11. Mills, W. H.; Nixon, I. G. J. Chem. Soc. 1930, 2510.

12. Alkorta, I.; Elguero, J. Struct. Chem. 1997, 8, 189.

13. Ramos, M.; Alkorta, I.; Elguero, J. Tetrahedron 1997, 53, 1403.

14. Abboud, J. L. M.; Cabildo, P.; Cañada, T.; Catalán, J.; Claramunt, R. M.; de Paz, J. L. G.; Elguero, J.; Homan, H.; Notario, R.; Toiron, C.; Yranzo, G. I. J. Org. Chem. 1992, 57, 3938.

15. El Hammadi, A.: El Mouhtadi, A. Theochem 2000, 497, 241.

16. Jaronczyk, M.; Dobrowolki, J. C.; Mazurek, A. P. Theochem 2004, 673, 17.

17. Martins, M. A. P.; Bastos, G. P.; Sinhorin, A. P.; Zimmermann, N. E. K.; Rosa, A.; Brondani, S.; Emmerich, D.; Bonacorso, H. G.; Zanatta, N. J. Fluorine Chem. 2003, 123, 249.

18. Martins, M. A. P.; Pereira, C. M. P.; Zimmermann, N. E. K.; Cunico, W.; Moura, S.; Beck, P.; Zanatta, N.; Bonacorso, H. G. J. Fluorine Chem., 2003, 123, 261.

19. Becke, A. D. Phys. Rev. A 1988, 38, 3098; Becke, A. D. J. Chem. Phys. 1993, 98, 5648; Lee, C.; Yang, W.; Parr, R. G. Phys. Rev. B 1988, 37, 785.

20. Ditchfield, R.; Hehre, W. J.; Pople, J. A. J. Chem. Phys. 1971, 54, 724.

21. Eliel, E. L.; Wilen, S. H. Stereochemistry of Organic Compounds, John Wiley, New York, 1994, p. 764. 